\title{
Evaluating the Organizational Culture Types of the 5-Star Hotel's in Istanbul in terms of the Cameron \& Quinn Competing Values Model
}

\section{İş Görenlerin Algıladıkları Örgüt Kültürü Tiplerini Belirlemeye Yönelik Bir Araştırma: İstanbul'da Faaliyet Gösteren 5 Yıldızlı Oteller Örneği}

\author{
Merve Oz, Istanbul University, Turkey, merve.oz@istanbul.edu.tr \\ Fazıl Kaya, Istanbul University, Turkey, fazil.kaya@istanbul.edu.tr \\ Ibrahim Ciftci, Istanbul University, Turkey, ibrahim.cifci@istanbul.edu.tr
}

\begin{abstract}
Organizational culture is the combination of the beliefs, values, behavior norms, formal and informal system processes and methods. As of 1980, the organizational culture, which is an important phenomenon in business management, has become a dominant issue in defining the behaviors of the employees in tourism businesses. Organizational culture in hotel businesses ensures that the employees are motivated towards acting against uncertainties with a mutual purpose, and that they move in a safe path. In this study, the 5-star hotels in Istanbul have been evaluated in terms of organizational culture types (Adhocracy, Klan, Bureaucracy and Market) set by Cameron and Quinn "Competing Values Model". In the study context, 335 employees replied to questionnaires in 5-star hotels. According to the results of the study, the findings suggested that the mean values of the organizational culture types are higher; however, there are no clear differences among culture types.
\end{abstract}

Keywords: Organizational Culture, Organizational Culture Types, Hotel Businesses, Competing Values Model

Öz: Örgüt kültürü, işletmelerdeki inanç ve değerler, davranış normları, formal ve informal sistem süreç ve yöntemlerin bir birleşimdir. 1980'den itibaren işletme alanında önemli bir görüngü olan örgüt kültürü, turizm işletmelerinde de iş görenlerin davranışların tanımlamada önemli bir konu haline gelmiştir. Turizm işletmelerinden biri olan otel işletmelerinde örgüt kültürü, iş görenleri ortak bir amaç doğrultusunda belirsizliklere karșı hareket ettirmeye ve iş görenlere güvenli bir yolda ilerlemeyi sağlamaktadır. Bu araștırmada, İstanbul' da hizmet veren 5 yıldızlı otel işletmelerinde Cameron ve Quin'in ortaya koyduğu "Rekabetçi Değerler Modeli" kapsamında örgüt kültürü tipleri (Adokrasi, Klan, Bürokrasi ve Pazar) açısından değerlendirilmesi yapılmıştır. Araştırma kapsamında, beş yıldızlı otellerde 335 iş görene anket uygulanmıştır. Araştırma sonucunda ise, örgüt kültürü tipleri ortalamalarının oldukça yüksek olduğu ancak aralarında belirli bir farkın olmadığı görülmüştür.

Anahtar Kelimeler: Örgüt Kültürü, Örgüt Kültürü Tipleri, Otel İşletmeleri, Rekabetçi Değerler Modeli

\section{Introduction}

Culture is a complex and integrated whole consisting of information, art, traditions, skills and habits that have been learnt (acquired) by human beings as a part of a society. Culture is separated into two concepts as tangible and intangible culture. The tangible culture consists of tools, devices, buildings and technologies formed by the human beings; while the intangible culture consists of elements such as values, behaviors and rules that form the cultural structure of the society. Today, it is not possible to consider institutions and businesses as separated entities from the culture (Jackson and Carter, 2007). Morgan (1998), defines the organizational culture as the system of beliefs and values formed by the employees; while Schein (2010), describes organizational culture as a social phenomenon and as a whole consisting of ideas and thoughts that keep the employees together.

Organizational culture is a distinctive feature for many successful businesses that can go beyond the normal financial cycle and that can continue to exist in heavy competition environment together with the effects of globalism (Román et al, 2004). The books of Deal and Kennedy named "Organizational Culture" and Peters and Waterman's "In Search of Excellence" have contributed greatly to the inclusion of the organizational culture concept in the literature. Deal and Kennedy emphasized that a powerful organizational culture structure and the commitment of the employees to the organization are interrelated with each other as two concepts. Therefore, a powerful organizational structure increases understanding of the organization objective and strategy. For this reason, it may be suggested that businesses became increasingly aware of the ways that an organizational culture may affect employees and organizations. This situation may have a positive effect on the attitudes and motivations of the employees (Deal and Kennedy, 1982; Peters and Waterman, 1984 ; Dawson, Abbott, and Shoemaker, 2011: 291; Baum, 2008; Deery and Shaw, 1999; Lund, 2003).

The tourism industry has a more dynamic organizations cultural structure than other industries. Customer experience shows an intangible characteristics due to the customer satisfaction depends on the performance of the employees who get contact with customer face to face in service process. Especially, hotel organizations that face 
rapidly changing customer demands derive their primary competitive advantage by encouraging employees' for well service understanding (Tsai et al, 2015:27).

The purpose of this study is to examine the organizational culture profiles of 5-star hotels in Istanbul in order to clarify the organizational culture structures of these businesses by using the four different organizational culture types (Adhocracy, Klan, Bureaucracy and Market) developed by Cameron and Quinn (1999).

\section{Literature Review}

Organizational culture consists of values, behaviors, beliefs, ritual, norms, expectations and socializing which effect the behaviors of the employees in a business. Numerous studies suggest that the organization culture has an evident influence on the productivity, efficiency, and commitment of the employees in a business (Nango and Ikyanyon, 2012; Deal and Kennedy, 1982; Clugston, 2000). For these reasons, it may be suggested that organizational culture is related with the structure of the business. According to Obeng and Ugrboro (2003), company's most fundamental responsibility is to improve employees' skills, efficiencies and commitment of the employees for the organization. Kocaman et al. (2012) stated that the importance of forming an organizational culture in the context of common values in accommodation facilities in terms of tourism sector.

Organizational culture affects both the organizational factors and employees' demographic structure. Cohen (1993), stated that there was a significant relation between the ages of the employees and tenure with the organizational commitment. Organizational culture perception can be affected by demographic characteristics of employee (Hofstede et al., 1990; Helms and Stern, 2001; Sayl1, Baytok, \& Soybal1, 2010). According to Luthans et al, (1987), demographic factors include the age, gender, educational status, and working duration. The age of the individuals lead to difference in terms of their attitudes towards working. However, in a study conducted by Brown, Arendt and Bosselman (2014), it was reported that individuals with higher educational background made more effective decisions in terms of their career planning. In the study of Nango and Ikyanyon (2012), it was stated that forming and developing an effective organizational culture would ensure that the organization is successful. Therefore, it may be suggested that organizational culture effects the commitment of the employees to the organization, enables them to have an identity and makes them feel a part of their organization. Ozkan and Gumus (2013) conducted a study "on the effects of organizational culture in hotel businesses on the conversion of job values, and reported that the employees who work for longer durations in the workplace have settled job values and organizational culture more than those who work for less durations.

A review of the literature reveals that numerous studies have examined the organizational culture. Hofstede's “Culture Approach", Schein's “Organizational culture Model”, Pearson's “AGIL Model”, "Peters and Waterman's Model" and Quinn and Rohrbaugh's "Competitive Values Approach" organizational culture models are among the works that dealt with this topic. Cameron and Freeman's "Competitive Values Approach" and the "Organizational Culture Type", Goffee and Jones's “Two-Dimensional Organization Type”, "Jeffrey Harrison Organizational Culture Type", "Deal and Kennedy Organizational Culture Type", "Handy Organizational Culture Type" and "Ouchi Organizational Culture Type" Erdem, (2010), are among the most common organizational culture typologies that have been developed as based on the organizational culture models and approaches.

The basis of the "Competing Values Model" which is used in the analysis of organizational culture type is based on the organizational culture approach stated in the "A spatial model of effectiveness criteria: toward a competing values approach to organizational analysis" by Robert E. Quinn and John Rohrbaug (Quinn and Rohrbaugh , 1983). This model has been revised in 1999 by Cameron and Quinn. The authors published the "Diagnosing and changing organizational culture: Based on the competing values framework" in 1999 and revised the organizational culture model. This model is based on the findings of the "Competing Values Model" which is performed for determining the organizational efficiency and organizational culture relationship (Kwan and Walker, 2004).

According to the Cameron and Quinn's organizational culture type, each organizational culture type demonstrates the development and change level of the organization. Cameron and Quinn make use of four different culture typologies and explain the cultural structure in organizations. These four different culture typologies are, human relations and development (clan) culture; hierarchy (bureaucracy) culture; market culture; and harmony with the environment (adhocracy) culture. It is suggested that the cultural structure of each organization may be inclined to one of these typologies. These organizational culture typologies are explained below (Cameron and Quinn , 2006; Masood et al, 2006, 944);

- Clan Culture: Clan Culture is an organizational culture type that focuses on the internal processes and that has a flexible structure. This type is named as "clan" because it resembles a family. The Clan Culture is observed in organizations where shared values, targets, commitment, participation, individualism and the sense of "we" are dominant. The Clan in the Competing Values Model is explained as the type in which employees share and develop friendly relations.

- Bureaucracy Culture: Bureaucracy Culture is observed in organizations where there is a hierarchical structure. Procedures define what the employees will do or will not do. The most important issue in 
Bureaucracy Culture is the continuation of problem-free work. Formal rules and policies are considered among the most important features that keep the organization together. Bureaucracy organizational culture type is usually observed in the management structures of the big organizations and state institutions.

- Market Culture: This model deals with the organization as a market structure. The market term used in this model does not has neither a marketing function nor a meaning that constitutes the customers in a market place. The success and superiority of the organizations in the competition, increasing market share and reaching higher targets in production are among important issues in this culture type. The factor that keeps such organizations together is the sense of winning. Focusing on success, results and the targets, and productivity are among the basic purposes in this type.

- Adhocracy Culture: This organization type has a structure that characterizes today's organizational world and has the fastest reaction in the competition conditions. Due to the fact that decrease in the dynamics in products and services, some assumptions have been proposed, which is different from the other three organization types. These assumptions are, considering the initiatives that may lead to innovative ideas, suggesting innovative ideas in developing new products, empowering the entrepreneurship and creativity of the managers.

According to Katz and Kahn, the most important advantage of the organizational culture typologies is to contribute to the organizational behaviors diversity and through the help of this diversity, decreasing the unexpected risk (Altman and Baruch, 1998). The purpose of the classification in culture typologies is examine the clear properties of the organizations and the strong and weak side of these organizations. Learning the current culture type gives the skill of estimating the change in the cultural elements that will help to remove current problems or to encourage development of managers in the organization.

\section{The Methodology of the Study}

\subsection{The Purpose of the Study}

Recently, the organizational culture has become an important and obvious concept in the management and organization culture in terms of contributing greatly to the competitiveness and sustainability of the organizations. The purpose of the study is to examine the viewpoints of the employees of 5-Star hotels in Istanbul by using Cameron and Quinn's organizational culture types which is one of the organizational culture models.

The demographic characteristics of the employees will create a meaningful difference on the organizational culture and makes it important to examine the relations between the demographic characteristics of the employees. The sub-purposes of the study were determined by being inspired by the study conducted by Cohen (1993) "Age and Tenure in Relation to Organizational Commitment". The sub-purpose of study;

- Determine the issues like which organizational culture types are emphasized in 5-Star hotels in Istanbul,

- The age groups of the hotel employees,

- Their durations in the sector and the relations among these issues.

The increasing number of hotels in Istanbul, the population density, considering the city being and the center of commercial activity in Turkey increases the attractiveness of the city and show the importance of competition conditions in the tourism market.

\subsection{Sample of the Study}

The employees of 5-Star hotels in Istanbul constitute the universe of the study. However, because of the difficulty in reaching all the hotel employees during the study and due to limitations in time and finance, the convenience sampling has been used. The most important reason for choosing the 5-Star hotels in Istanbul is that the employees in this city may have a management approach which is more professional when compared with other seasonal areas. It is considered that this situation will be influential on the results of the study.

\subsection{The Method of the Study}

In order to determine the organizational culture types of the employees working in the hotel businesses in Istanbul, "Organizational Culture Assessment Instrument" which has been developed with 20 items on the basis of Cameron and Quinn (1999), "Competing Values Framework"' has been used. The questionnaire was taken from Oztop' (2008) study. The questionnaire consists of four organizational culture types which are human relations and development (clan) culture; hierarchy (bureaucracy) culture; market culture; and harmony with the environment (adhocracy) culture. In total, 450 questionnaires was distributed to the employees and 376 out of 450 was returned between the date July and August, 2014. 335 questionnaires that met the criteria for the study were 
used. The questions on demographic properties and organizational culture with in four dimensions have been dealt. Each statement in these four dimensions cover the four organizational culture type (Clan, Hierarchy, Adhocracy, and Market). The scale has been formed in 5-Point Likert Scale and the expressions in the scale have been evaluated as "I don't agree at all (1), "I don't agree" (2), "I am undecided" (3), "I agree" (4) and "I totally agree" (5). The questionnaires have been analyzed with the SPSS 21 Statistical Program. The data obtained were analyzed in the light of the obtained data with the demographic properties of the participants and the questions were subjected to factor analysis. The Kolmogorov Smirnov test has been applied in order to determine whether the data show normal distribution or not. The result of the test was $\mathrm{P}<0,05$, and for this reason, it has been determined that the data do not show a normal distribution and are non-parametric. Therefore, the Kruskal-Wallis variance analysis has been made use in order to understand whether the organizational culture types show a meaningful difference according to the age distribution or not.

\section{The Findings of the Study}

\subsection{Demographic Findings}

When the demographic of the employees in the hotels are examined, it was observed that $\% 82,7$ of the participants were men, $\% 17,3$ of the participants were women. When the ages of the participants are considered, it has been observed that the \%62,4 of the participants were between 18-30; and \%26,9 were between 35-45; and \%10,7 of them were between $46-60$. In terms of the education levels, $\% 14$ were at the primary school level; $\% 23$ were at the secondary school level, and $\% 63$ of them are at the high school level. When the duration of work of the participants is examined, it has become obvious that $\% 64,2$ of them had worked between 1-5 years, \%25, 7 of them had worked between 6-10 years, and \%10, 1 of them between 11-15 years.

\subsection{Empirical Findings}

For the factor analysis, the Kaiser-Meyer-Olkin (KMO) coefficient and the Barlett Sphericity Test is examined. In the scope of this study, the KMO coefficient has been determined as ,906 which is a higher value. The Barlet Sphericty test value has been found as (Psig= $, 000 ; \mathrm{P}<0,05)$. After the reliability test performed on 20 questions, the Cronbach Alpha coefficient has been found as 0,967 . These results showed consistency for the factor analysis (Nunnally, 1967).
Table 1. KMO and Bartlett's Test

\begin{tabular}{|l|l|l|}
\hline Kaiser-Meyer-Olkin (KMO) &, 906 \\
\hline \multirow{2}{*}{ Barlett Sphericity } & Approx. Chi-Square & 7297,91 \\
Test & Df & 190 \\
& Sig. &, 000 \\
\cline { 1 - 1 } Cronbach Alpha & N of Items: 20 &, 967 \\
\hline \multicolumn{2}{|l}{ P<0,05) } \\
\hline
\end{tabular}

Table 2. Organizational Culture Type Factors

\begin{tabular}{|l|c|c|c|}
\hline Factors & \multicolumn{1}{|l|}{ Mean } & Standart Deviation & Cronbach Alfa \\
\cline { 1 - 2 } Adhocracy & 3,753 &, 969 &, 877 \\
\cline { 1 - 1 } Clan & 3,921 &, 925 &, 909 \\
\cline { 1 - 3 } Bureaucracy & 3,934 &, 841 &, 880 \\
\cline { 1 - 2 } Market & 3,998 &, 969 &, 923 \\
\hline
\end{tabular}

When Table 2 is examined, it is observed that the mean values of the factors are close to each other and high. However, the "market" organizational culture type, which is among the factor dimensions, has been observed as having a higher average when compared with the other dimensions. When the competitive structure of the tourism industry is considered, the fact that this dimension has come to the front line is meaningful for the hotel businesses in Istanbul. 
Table 3. Organizational Type Perceptions of the Participants According to the Age Variable

\begin{tabular}{|c|c|c|c|c|c|}
\hline Factors & Age & $\mathbf{N}$ & Mean Rank & Chi-Square & Assymp. Sig(p) \\
\hline \multirow{4}{*}{ Adhocracy } & $18-30$ & 209 & 173,07 & 25,305 &, 000 \\
\hline & $31-45$ & 90 & 133,14 & & \\
\hline & $46-60$ & 36 & 225,72 & & \\
\hline & Total & 335 & & & \\
\hline \multirow{4}{*}{ Clan } & $18-30$ & 209 & 177,82 & 11,839 & ,003 \\
\hline & $31-45$ & 90 & 138,36 & & \\
\hline & $46-60$ & 36 & 185,11 & & \\
\hline & Total & 335 & & & \\
\hline \multirow{4}{*}{ Bureaucracy } & $18-30$ & 209 & 177,39 & 12,783 & ,002 \\
\hline & $31-45$ & 90 & 137,64 & & \\
\hline & $46-60$ & 36 & 189,40 & & \\
\hline & Total & 335 & & & \\
\hline \multirow{4}{*}{ Market } & $18-30$ & 209 & 174,44 & 18,141 & ,000 \\
\hline & $31-45$ & 90 & 136,02 & & \\
\hline & $46-60$ & 36 & 210,56 & & \\
\hline & Total & 335 & & & \\
\hline
\end{tabular}

As it is observed in Table 3, a meaningful difference has been observed between the organizational types and the age values of the participants. It is observed that the mean rank between the 46-60 age group and the other age groups vary greatly. The average of the mean ranks of the 46-60 age group has been determined as adhocracy: (225,72); clan: $(185,11)$; bureaucracy: $(189,40)$; and market: $(210,56)$.

Table 4. Organizational Type Perceptions of the Participants According to the Professional Experience

\begin{tabular}{|c|c|c|c|c|c|}
\hline Factors & Experience & $\mathbf{N}$ & Mean Rank & Chi-Square & Assymp. Sig(p) \\
\hline \multirow{4}{*}{ Adhocracy } & $1-5$ & 215 & 161,89 & \multirow[t]{4}{*}{4,682} & \multirow[t]{4}{*}{, 096} \\
\hline & $6-10$ & 86 & 170,64 & & \\
\hline & $11-15$ & 34 & 199,99 & & \\
\hline & Total & 335 & & & \\
\hline \multirow{4}{*}{ Clan } & $1-5$ & 215 & 171,81 & \multirow[t]{4}{*}{1,063} & \multirow[t]{4}{*}{,588 } \\
\hline & $6-10$ & 86 & 159,23 & & \\
\hline & $11-15$ & 34 & 166,12 & & \\
\hline & Total & 335 & & & \\
\hline \multirow{4}{*}{ Bureaucracy } & $1-5$ & 215 & 160,72 & \multirow[t]{4}{*}{14,757} & \multirow[t]{4}{*}{,001 } \\
\hline & $6-10$ & 86 & 162,52 & & \\
\hline & $11-15$ & 34 & 227,91 & & \\
\hline & Total & 335 & & & \\
\hline \multirow{4}{*}{ Market } & $1-5$ & 215 & 167,87 & \multirow[t]{4}{*}{,305 } & \multirow[t]{4}{*}{,858 } \\
\hline & $6-10$ & 86 & 171,26 & & \\
\hline & $11-15$ & 34 & 160,57 & & \\
\hline & Total & 335 & & & \\
\hline
\end{tabular}

As it is clear in Table 4, it has been determined that there is a meaningful difference between the bureaucracy organizational culture type and the professional experience. When the professional experiences considered, it has been observed that the employees who had worked for 11-15 years had different mean rank when compared with the other employees. It may be observed in the results of the analysis that there is not a meaningful difference between the adhocracy $(, 096)$, clan $(, 588)$ and market $(, 858)$ organizational culture type and the professional experience of the employees.

\section{Result}

Organizations can continue their existences in today's competitive conditions, increase their success and activities, and ensure that their employees are committing to their organizations only by having a strong organizational culture. For this reason, the definition of the cultural structure of an organization by itself depends on the employees' understanding the targets of their organization and increase their performances in terms of 
organizational purposes. In this context, the basic aim of this study is to examine the organizational culture type of 5-Start hotels in Istanbul by using the "Competing Values Framework" analysis developed by Cameron and Quinn. The organizational structure may show differences due to the seasonal work, which is the characteristics of the tourism industry, the employee turnover rate being higher, and the product showing intangible characteristics.

In this study, organizational culture type has been studied in hotel businesses. It has been determined that there is not a certain inclination in terms of the culture typologies. It has been analyzed that the average values of the Organizational culture types are high. It may be suggested that the Market type is high in hotel businesses when compared with the other typologies; however, it may also be suggested that there is not a distinctive difference.

Kocaman et al. (2012) conducted a study to examine the effects of organizational culture in Accommodation Facilities on Conflict and emphasized that forming an Organizational Culture in the context of common values within accommodation facilities was important for the sector. No distinguishing differences were found between the data obtained and the organizational culture types. Therefore, this leads us to the idea that forming an organizational culture around the "common values" is important for 5-star hotel businesses.

Upon the significance tests conducted to determine whether Organizational culture type show difference according to demographic characteristics or not, it has been determined that the analyses show differences in terms of the age and professional experiences levels of the participants. Luthans et al. (1987), conducted a study and reported that the attitudes of the employees on organizational culture according to the age variable showed significance. In addition, in the studies of Hofstede, et al. (1990); Helms and Stern, (2001); Sayl1 et al., (2010) stated that organizational culture perception can be affected by demographic characteristics of employee. In this study, it has been determined that there is a meaningful difference between the age and the organizational culture types, and that there is also a meaningful difference between the 40-60 ages group employees and the other age groups. Furthermore, a significance relation has been found only in the Bureaucracy organizational culture type. A distinctive difference has been determined in the employees who had worked for an organization for long years. Cohen (1993), emphasized in his study that there is a significant relation between the age of the employees and professional experiences with the organizational commitment.

Ozkan and Gumus (2013) conducted a study on the effects of the organizational culture in hotel businesses on the conversion of job values and reported that the employees who work for longer durations in the workplace have settled job values and organizational culture when compared with those who work for less durations. In this study too, it has been determined that the long-term employees have adopted the organizational culture typology in a more dominant manner than the short-term employees in terms of sector experience.

The organizational culture typologies, which constitute the basic focal point of this study, consist of many sub-elements. In this study, the issue has been examined in terms of the viewpoints of the employees to determine the organizational culture typologies; however, the fact that the administrative and dimensional issues such as leadership style, harmonization, and strategy being not included in determining the organizational culture typologies constitute the limitations of the study. In future studies, the organizational culture must be examined both in terms of employees and the administration to create a difference.

To conclude, this study aims to reveal the current status of the organizational culture type inclinations in tourism organizations. It may be concluded that the organizations which are in the scope of this study do not have a specific organizational culture type. Further studies may be conducted on organizational culture and the motivation, performance, leadership etc. characteristics which guide the structure of the organizational cultures type. 


\section{References}

Altman, Y., \& Baruch, Y. (1998). Cultural Theory and Organizations: Anlaytical Method and Cases. Organization Studies, 769-785.

Baum, T. (2008). Implications of hospitality and tourism labour markets for talent management strategies. International Journal of Contemporary Hospitality Management, 720-729.

Brown, E. A., Arendt , S., \& Bosselman , R. (2014). Hospitality Management Gradutes' Perceptions of Career Factor Importance and Career Factor Experince . International Journal of Hospitality Management, 5867.

Cameron, K. S., \& Quinn, R. (2006). Diagnosing and Changing Organizational Culture: Based on the Competing Values Framwork. San Francisso : The Jossey- Boss: Business and Management Series .

Clugston, M. (2000). The Mediating Effects of Multidimensional Commitment on Job Satisfaction and İntent to Leave. Journal of Organizational Behavior , 477-486.

Cohen, A. (1993). Age and Tenure in Relation to Organizational Commitment: A Meta-Analysis. Basıc and Applied Social Psychology, 143-149.

Dawson, M., Abbott, J., \& Shoemaker, S. (2011). The Hospitality Culture Scale: A Measure Organizational Culture and Personel Attributes. International Journal of Hospitality Management, 30(2), 290-300.

Deal, T. E., \& Kennedy , A. (1982). A Corporate Culture. Reading : M.A. Addison Wesley.

Deery, M. A., \& Shaw, R. (1999). An investigation of the relationship between employee turnover and organizational culture. Journal of Hospitality \& Tourism Research, 387-400.

Erdem, T. (2010). Örgüt Kültürü Işsletmelerin Başarısındaki En Temel Paradigma. İstanbul: Beta Yayınları.

Helms, M., \& Stern, R. (2001). Exploring the Factors that Influence Employees‘ Perceptions of their Organization‘s Culture. Journal of Management in Medicine, 15(6), 415-429.

Hofstede, G., Neuijen, B., Ohayv, D., \& Sanders, G. (1990). Measuring Organizational Cultures: A Qualitative and Quantitative Study Across Twenty Cases. Administrative Science Quarterly, 35(2), 286-316.

Jackson, N., \& Carter, P. (2007). Rethinking Organisational behavior: A Potstructuralist Framwork. Leicester: Prentice Hall/ Finacel Times.

Kocaman, S., Kocaman , S., \& Neşe, Ç. (2012). Konaklama İşletmelerınde Örgüt Kültürünün Örgütsel Çatışma Üzerıne Etkilerı: Alanya Bölgesınde Bır Araştırma. Sosyal Bilimler Enstitüsü Dergisi, 167-183.

Kwan, P., \& Walker , A. (2004). Validaitng the Competing Values Models as a Representation of Organizational Culture Through Inter-Instutional Comprasions. Organizational Analysis, 21-37.

Lund, D. B. (2003). Organizational Culture and Job Satisfaction . Journal of Business \& Industrial Marketing, 219-236.

Luthans, F., Baack, D., \& Taylor, L. (1987). Organizational Commitment: Analysis of Antecedents. Human Relations, pp. 219-236.

Masood, S. A., Dani, S., Burns , N., \& Backhouse, C. (2006). Transformational Leadership and Organizational Culture: The Situational Strength Perspective. Proceedings of the Institution of Mechanical Engineers. Journal of Engineering Manufacture, 941-949.

Morgan, G. (1998). Images of Organization. San Francisco: Berrett-Koehler Publishers.

Nango, E. S., \& Ikyanyon, D. (2012). The Influence of Corporate Culture on Employee Commitment to the Organization. International Journal of Busniness and Management, 1833-8119.

Nunnally, P. (1967). Psychometic Theory. New York: McGraw Hill.

Obeng, K., \& Ugboro, I. (2003). Organizational Commitment among Public Transit Employees: an Assessment Study . Journal of the Transportation Reserach Forum, 83-98.

Özkan, Ç., \& Gümüş, M. (2013). Ege Bölgesindeki 4-5 Yıldızlı Otel İşletmelerinde Örgüt Kültürünün İş Değerlerinin Dönüşümüne Etkileri. KMÜ Sosyal ve Ekonomik Araştırmalar Dergisi, 01-14.

Peters, T., \& Waterman, R. (1984). In Search of Excellence: Lessons from America's Best-Run Companies. . Newyork : Harper \& Row Publisher.

Quinn, R. E., \& Rohrbaugh , J. (1983). A Spatial Model of Effectiviness Criteria: Towards a Competing Values Approach to Organizational Analysis . Management Science, 363-377.

Román, J. A., M. Ribière, V., \& Stankosky, M. (2004). Organizational Culture Types and their Relationship with Knowledge Flow and Knowledge Management Success: An Empirical Study in the U.S. Government and Nonprofit Sectors. Journal of Information\& Knowledge Management, pp. 66-91.

Sayl, H., Baytok, A., \& Soybal1, H. (2010). The Effects of Employees' Demographic Characteristics on the Perception of Organizational Culture: A Study in Service Enterprise. 2nd International Symposium on Sustainable Development, (s. 198-204). Sarajevo.

Schein, E. H. (2010). Organizational Culture and Leadership (4 ed.). San Francisco: John Wiley \& Sons. 
Tsai, C.-Y., Horng, J.-S., Liu, C.-H., \& Hu, D.-C. (2015). Work Environment and Atmosphere: The Role of Organizational Support in the Creativity Performance of Tourism and Hospitality Organizations. International Journal of Hospitality Management, 26-35. 